\title{
Genetics of inherited cardiomyopathies in Africa
}

\author{
Gasnat Shaboodien ${ }^{1,2}$, Timothy F. Spracklen ${ }^{1,2}$, Stephen Kamuli ${ }^{1,2}$, Polycarp Ndibangwi ${ }^{1,2}$, \\ Carla Van Niekerk ${ }^{1,2}$, Ntobeko A. B. Ntusi ${ }^{1,2,3}$ \\ ${ }^{1}$ Cardiovascular Genetics Laboratory, Hatter Institute for Cardiovascular Research in Africa, Department of Medicine, ${ }^{2}$ Department of Medicine, \\ ${ }^{3}$ Cape Universities Body Imaging Centre, Faculty of Health Sciences, University of Cape Town, Cape Town, South Africa \\ Contributions: (I) Conception and design: G Shaboodien, NA Ntusi; (II) Administrative support: C Van Niekerk; (III) Provision of study materials \\ or patients: None; (IV) Collection and assembly of data: TF Spracklen, S Kamuli, P Ndibangwi, Van Niekerk; (V) Data analysis and interpretation: \\ G Shaboodien, TF Spracklen, S Kamuli, P Ndibangwi, NA Ntusi; (VI) Manuscript writing: All authors; (VII) Final approval of manuscript: All authors. \\ Correspondence to: Associate Professor Gasnat Shaboodien. Director, Cardiovascular Genetics Group, Hatter Institute for Cardiovascular \\ Research in Africa, Department of Medicine, University of Cape Town, Anzio Road, Observatory, 7925, Cape Town, South Africa. \\ Email: Gasnat.Shaboodien@uct.ac.za.
}

\begin{abstract}
In sub-Saharan Africa (SSA), the burden of noncommunicable diseases (NCDs) is rising disproportionately in comparison to the rest of the world, affecting urban, semi-urban and rural dwellers alike. NCDs are predicted to surpass infections like human immunodeficiency virus, tuberculosis and malaria as the leading cause of mortality in SSA over the next decade. Heart failure (HF) is the dominant form of cardiovascular disease (CVD), and a leading cause of NCD in SSA. The main causes of HF in SSA are hypertension, cardiomyopathies, rheumatic heart disease, pericardial disease, and to a lesser extent, coronary heart disease. Of these, the cardiomyopathies deserve greater attention because of the relatively poor understanding of mechanisms of disease, poor outcomes and the disproportionate impact they have on young, economically active individuals. Morphofunctionally, cardiomyopathies are classified as dilated, hypertrophic, restrictive and arrhythmogenic; regardless of classification, at least half of these are inherited forms of CVD. In this review, we summarise all studies that have investigated the incidence of cardiomyopathy across Africa, with a focus on the inherited cardiomyopathies. We also review data on the molecular genetic underpinnings of cardiomyopathy in Africa, where there is a striking lack of studies reporting on the genetics of cardiomyopathy. We highlight the impact that genetic testing, through candidate gene screening, association studies and next generation sequencing technologies such as whole exome sequencing and targeted resequencing has had on the understanding of cardiomyopathy in Africa. Finally, we emphasise the need for future studies to fill large gaps in our knowledge in relation to the genetics of inherited cardiomyopathies in Africa.
\end{abstract}

Keywords: Inherited cardiomyopathy; Africa; genetics; next generation sequencing; review

Submitted Jul 08, 2019. Accepted for publication Sep 29, 2019.

doi: $10.21037 / \mathrm{cdt} .2019 .10 .03$

View this article at: http://dx.doi.org/10.21037/cdt.2019.10.03

\section{Introduction}

With increased globalisation and modernisation, different regions are becoming progressively more interconnected through the movement of people, goods, capital and ideas. The health systems in sub-Saharan Africa (SSA) (Table S1) are consequently facing challenges imposed by a unique quadruple burden of increasing noncommunicable diseases (NCDs), persisting morbidity and mortality from communicable diseases, high maternal and infant mortality, and trauma and interpersonal violence (1-3). Combine these factors with changes in lifestyle, an ageing population and a healthcare environment that is marked by limited resources, short supply of well-equipped screening facilities, late diagnosis, and suboptimal care at primary, secondary, tertiary and quaternary levels, as well as a paucity of national 
level data on disease trends $(4,5)$, it is clear that SSA is facing a crisis in healthcare. The Global Burden of Disease study reported cardiovascular diseases (CVD) as the leading cause of mortality worldwide, and the second commonest cause of mortality after the human immunodeficiency virus (HIV)/acquired immune deficiency syndrome (AIDS) in SSA (6). CVD are predicted to surpass HIV/AIDS and other infections as the leading cause of death in SSA over the next decade $(7,8)$. The most common underlying cause of $\mathrm{HF}$ in high-income countries (HICs) is coronary artery disease (CAD) (9), but in SSA, the predominant causes are hypertension, cardiomyopathy, rheumatic heart disease (RHD) and pericardial disease $(1,10,11)$.

Remarkable progress over the past few decades has been made in the field of CVD, guided in particular by the continuously evolving classification systems for HF and cardiomyopathy. The role of cardiomyopathy in heart failure and as a healthcare burden in Africa has been reviewed elsewhere $(1,4,12,13)$. This review investigates the molecular genetics and incidence of the cardiomyopathies across the African continent with particular focus on the inherited cardiomyopathies such as dilated cardiomyopathy (DCM), hypertrophic cardiomyopathy (HCM), arrhythmogenic cardiomyopathy (ACM), restrictive cardiomyopathy (RCM) and left ventricular noncompaction (LVNC) (Table 1).

\section{Cardiomyopathies}

The cardiomyopathies (14) (Table 1) have been described as a group of morphofunctional cardiac disorders that are classified into familial/genetic and non-familial/nongenetic causes and are the major cause of sudden cardiac death (SCD) and HF in childhood and early adulthood. Cardiomyopathies are also associated with extensive genetic heterogeneity. Pathogenic mutations have been reported in cardiac sarcomere protein genes, cytoskeletal protein genes and nuclear envelope protein genes (15). There is increasing evidence that the clinical entities of DCM, HCM, ACM, RCM and LVNC share some disease genes with each other (16-18). Most cases occur sporadically, possibly pointing to de novo mutations.

Globally, the prevalence of cardiomyopathy is estimated at 2.5 million cases, an increase of $27 \%$ in 10 years (19) and can be caused by myocarditis, toxins, endocrinopathies, nutritional deficiencies, drugs and genetic abnormalities. In low- and middle income countries (LMICs), the prevalence of cardiomyopathy is considered to be higher than in
HICs; but as no population-based incidence or prevalence studies of HF or cardiomyopathy have been published, most of the available epidemiological data are gathered from hospital-based studies, often with variable application of established diagnostic criteria (20). In Southern Africa, hospital-based studies reported the highest prevalence of cardiomyopathy in SSA at $40.2 \%$, compared to East Africa where the prevalence was lowest at $18.2 \%$ (21-24). Agbor $e t a l$. reported that the risk of developing congestive $\mathrm{HF}$ is $30 \%$ higher in black Africans compared to their white counterparts, a finding that is not explained by the confounding variables of hypertension or socioeconomic factors (12). Treatment of patients with cardiomyopathies in LMICs is generally suboptimal as few patients take evidence-based combinations of diuretics, beta-blockers, angiotensin converting enzyme inhibitors (ACE-Is) and mineralocorticoid receptor antagonists (MRAs). Subsequently, mortality is high for African patients with HF $(22,23,25,26)$. Cardiomyopathy is an endemic form of NCD of high importance to the poor majority in SSA - and a locally relevant unmet need for research $(24,27)$.

To identify incidence studies for the inherited cardiomyopathies in Africa, we searched the PubMed, Web of Science, and Scopus databases for studies reporting on cardiomyopathy originating from Africa, including all referral-based case series, hospital and research studies. Studies reporting only on secondary or acquired causes of cardiomyopathy were excluded. The search produced 92 studies reporting on the incidence rates of DCM, HCM, ACM, RCM and LVNC in Africa (Table S2); these are discussed below. We are aware that hospitalbased studies are inherently biased due to non-random sampling techniques and that many of the selected studies' denominators are small and could reflect a strong selection and referral bias which may be misleading, however, they are included in this review for completeness. We reviewed the population size of the various African countries as well as the cardiologist-to-population ratio (where available) and found that some hospitals had catchment areas ranging from a few thousand to several million people.

\section{Dilated cardiomyopathy}

DCM is the most common cardiomyopathy, accounting for approximately $55 \%$ of cardiomyopathies (14), but as the prevalence rates for DCM has yet to be determined, we searched the literature for studies reporting on the incidence of DCM in Africa and found 52 articles 
Table 1 Definitions for the inherited cardiomyopathies

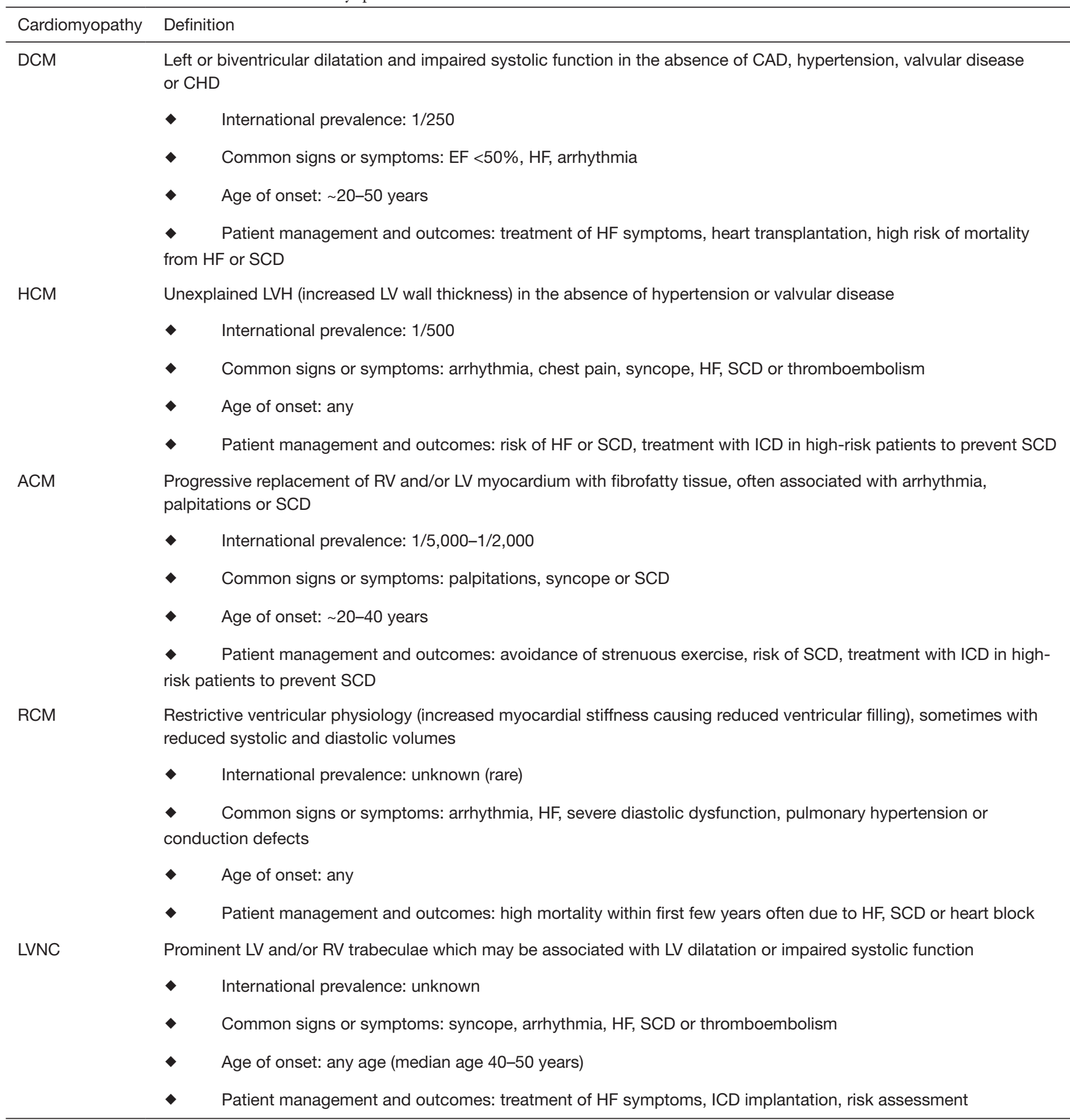

(Tables 2,S2), most of which were hospital-based studies. More than $67 \%$ of these studies were from Western and Eastern Africa, where the top two major causes of mortality from NCDs are documented as ischaemic heart disease and stroke. The largest of these studies occurred in Ethiopia $(n=6,275)$ and Malawi $(n=3,908)$ where 477 and 720 patients were reported to have DCM, respectively [Table $S 2(14,28)]$. The high incidence rates of DCM are supported by many 
Table 2 Incidence of cardiomyopathy in the five regions in Africa (Northern, Southern, Central, Eastern and Western)

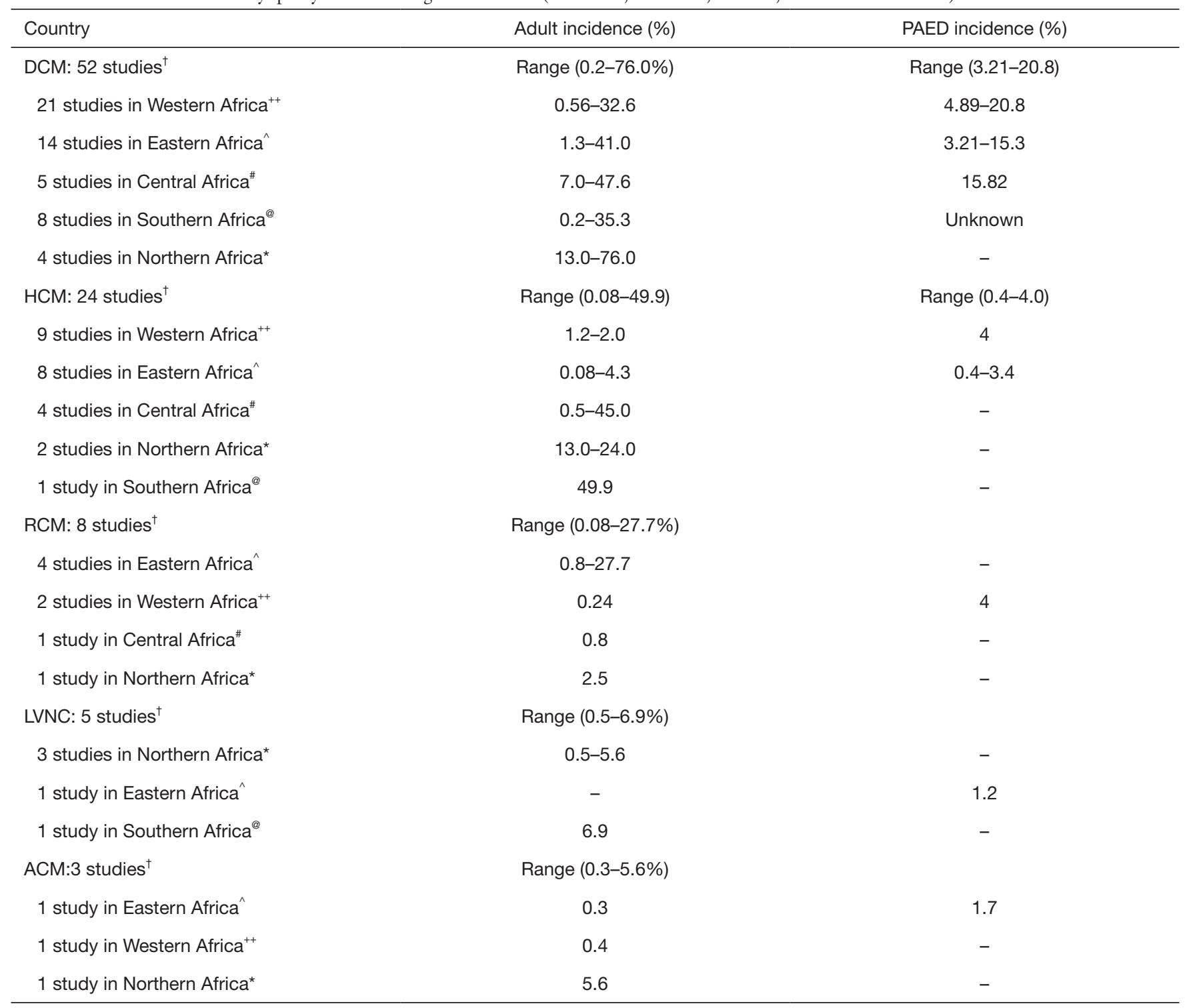

*, Northern Africa (7 countries): the northernmost part of the continent are Algeria, Egypt, Libya, Morocco, Sudan, Tunisia, Western Sahara; \#, Central Africa Central or Middle African countries (9 countries): Angola, Cameroon, Central African Republic, Chad, Congo RepublicBrazzaville, Democratic Republic of Congo, Equatorial Guinea, Gabon, and São Tomé \& Princip; ${ }^{\circledR}$, Southern Africa countries (5 countries): Botswana, Lesotho, Namibia, South Africa, and Swaziland; ’ , East Africa (19 countries): Burundi, Comoros, Djibouti, Ethiopia, Eritrea, Kenya, Madagascar, Malawi, Mauritius, Mozambique, Réunion, Rwanda, Seychelles, Somalia, Somaliland, Tanzania, Uganda, Zambia, and Zimbabwe; ${ }^{++}$, Western Africa (17 countries): Benin, Burkina Faso, Cape Verde, Côte D'Ivoire, Gambia, Ghana, Guinea, Guinea-Bissau, Liberia, Mali, Mauritania, Niger, Nigeria, Saint Helena, Senegal, Sierra Leone, and Togo. ${ }^{\dagger}$, Studies found in Table S2.

studies from various regions of Africa (Table S2).

\section{Genetics of DCM}

Up to $50 \%$ of DCM cases are familial, with many diseasecausing gene mutations described (29). The genetic forms of DCM usually result from mutated genes encoding 2 major subgroups of proteins: cytoskeletal and sarcomeric proteins $(15,30)$. In $20-50 \%$ of cases, DCM is inherited in an autosomal dominant manner, and nearly 60 different genes are involved (31). Among them, involvement of the sarcomeric gene, TTN is most prevalent (40\%), 
followed the nuclear lamin gene $L M N A$ (10\%) (32-34). Mechanistically, cytoskeletal proteins are cause defects of force transmission, resulting in the DCM phenotype, whereas defects of force generation have been speculated to be associated with sarcomere protein-induced DCM $(35,36)$. Mutations in desmosomal genes cause DCM and other forms of cardiomyopathy, and disrupt the links between the intercalated disk, Z-disk, and sarcomere (15).

To date, there is no published, large multicentre study of families in Africa whose members have been systematically clinically screened for DCM and have also undergone whole exome or genome sequencing to identify a possible genetic cause. We reviewed the available literature on the genetics of DCM in Africa and identified 9 studies (Table 3) that used a genetics approach in DCM cohorts. Six of the initial genetics studies (5 performed in South Africa) carried out from 1999 to 2010 aimed to determine the association of specific polymorphisms with differences in left ventricular $(\mathrm{LV})$ systolic performance or internal $\mathrm{LV}$ dimensions; changes in LV ejection fraction (LVEF); LVEF and LV end diastolic diameter (LVEDD); risk of HF, or severity or risk of progression of HF in high-risk DCM, with mixed findings (37-42). At least half of these studies found positive associations with LVH, improved LVEF and disease risk. The other genetics studies investigated the role of candidate genes in DCM. A study from our group screened the complete $P L N$ gene in a cohort of 95 DCM patients and found the previously reported PLN p.R9C mutation in a South African family with severe autosomal dominant DCM (44). As with a previous report, the PLN p.R9C mutation was detected in an individual with acute onset of DCM at the age of 21 years, leading to heart transplantation at 22 years of age (28). Even though mutations in PLN have been associated with DCM (68-70), HCM and ACM in North America and Europe, the role of $P L N$ in Africans with cardiomyopathy is unclear. Ours was the first report of a PLN mutation on the African continent and, in a screen of 315 patients comprising DCM, HCM, $\mathrm{ACM}$ and peripartum cardiomyopathy (PPCM), the PLN gene appeared to be a rare cause of cardiomyopathy in Africans (44). Finally, the only DCM study to have used NGS on the African continent was carried out in 2018 in a Moroccan family (32) where targeted resequencing was used to screen the DNA of five family members for 50 cardiomyopathy genes. The investigators found a previously reported pathogenic $L M N A$ p.R54C mutation as the cause of disease within this family.

The few studies that have emerged from Africa on the genetics of DCM are vastly inadequate and highlight an urgent need for comprehensive genetic testing of all DCM patients in Africa in order to understand the basic genetic milieu and to be able to treat patients accordingly.

\section{Hypertrophic cardiomyopathy}

HCM is considered a common form of cardiomyopathy in European and North American cohorts (8). A study from our group reported that while the annual mortality rate of $2.9 \%$ was high and the overall survival of $74 \%$ at 10 years was low compared to other series of patients with HCM (71), the survival rate was comparable to age- and gendermatched members of the South African population (61).

HCM was historically thought to be rare among Africans $(46,47,50,52,72)$. This impression was reinforced by a Tanzanian study that found HCM to occur in $0.2 \%$ of 6,680 unselected echocardiograms (73) however, echocardiographic studies from Ghana (74) have reported HCM to be the third commonest cardiomyopathy after DCM and endomyocardial fibrosis (EMF) (10) and in Ethiopia, HCM accounts for $34 \%$ of all cardiomyopathies diagnosed on echocardiography (75). However, there is little information on the incidence, prevalence, clinical features, genetics and outcome of HCM from the African continent, with a few publications reporting on HCMcausing mutations in South Africans of northern European descent and mixed ancestry $(46,47,50,52)$. In 2016, we reported on the first prospective investigation of the clinical characteristics, genetics and outcome of HCM in Africans. We found HCM to occur predominantly in men, with a young age of onset, including black Africans, and with a positive family history of HCM in the majority. The major symptoms and complications were similar to those reported in North American, Middle Eastern and Asian studies $(61,71)$.

In order to obtain an estimation of the incidence of HCM in Africa, we searched the literature for studies reporting on the incidence of HCM in Africa and found 24 articles (Tables 2,S2), most of which were hospital-based studies. The largest of these studies were from Tanzania $(\mathrm{n}=6,680)$, Ethiopia $(\mathrm{n}=6,275)$ and Malawi $(\mathrm{n}=3,908)$ where 134, 21 and 3 patients were reported to have HCM, respectively $(73,76,77)$. The very wide distribution ranges for the incidence rates of HCM in Africa could also be explained by small study sizes, limited resources, short supply of well-equipped screening facilities, late diagnosis and underdiagnosis. 


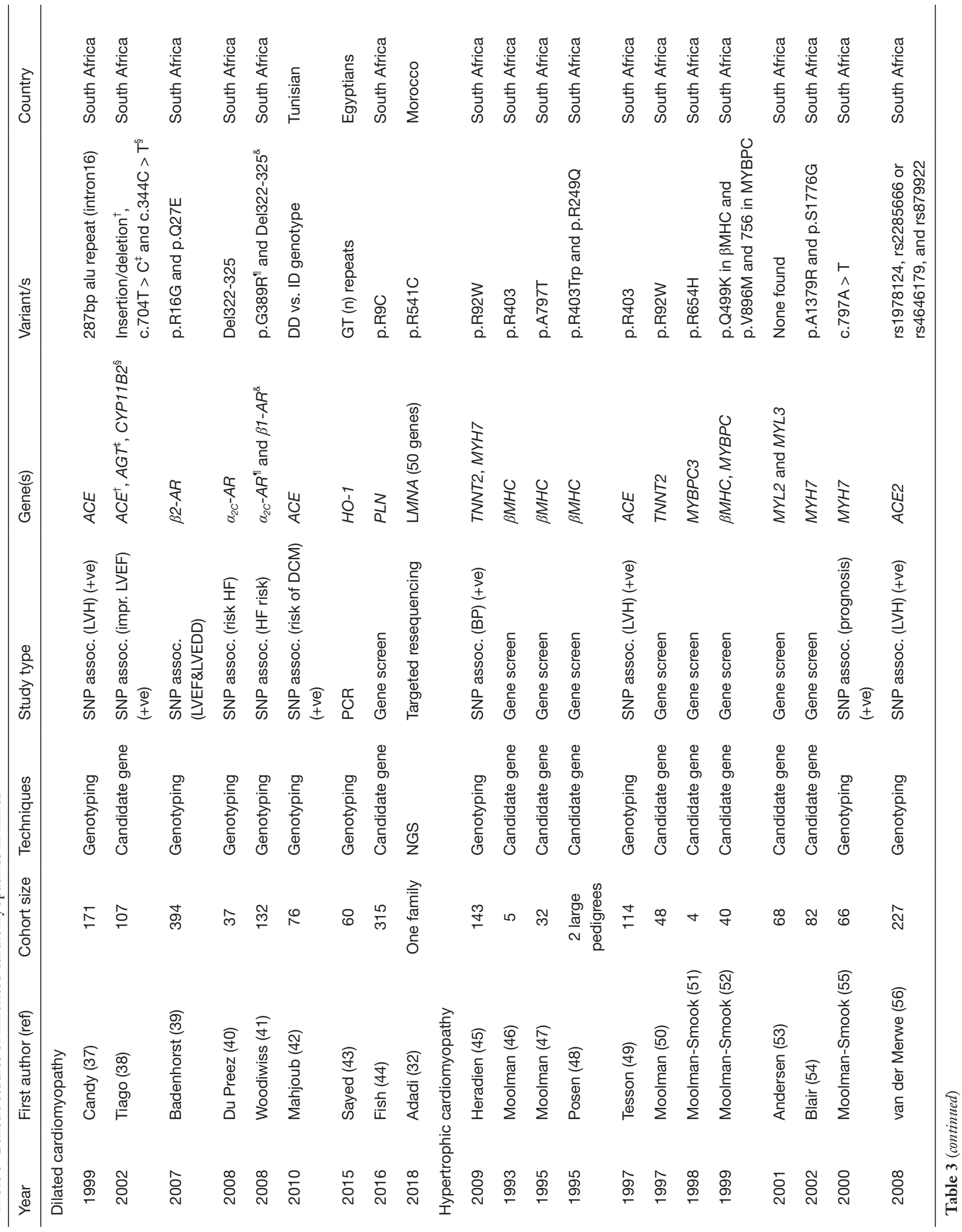




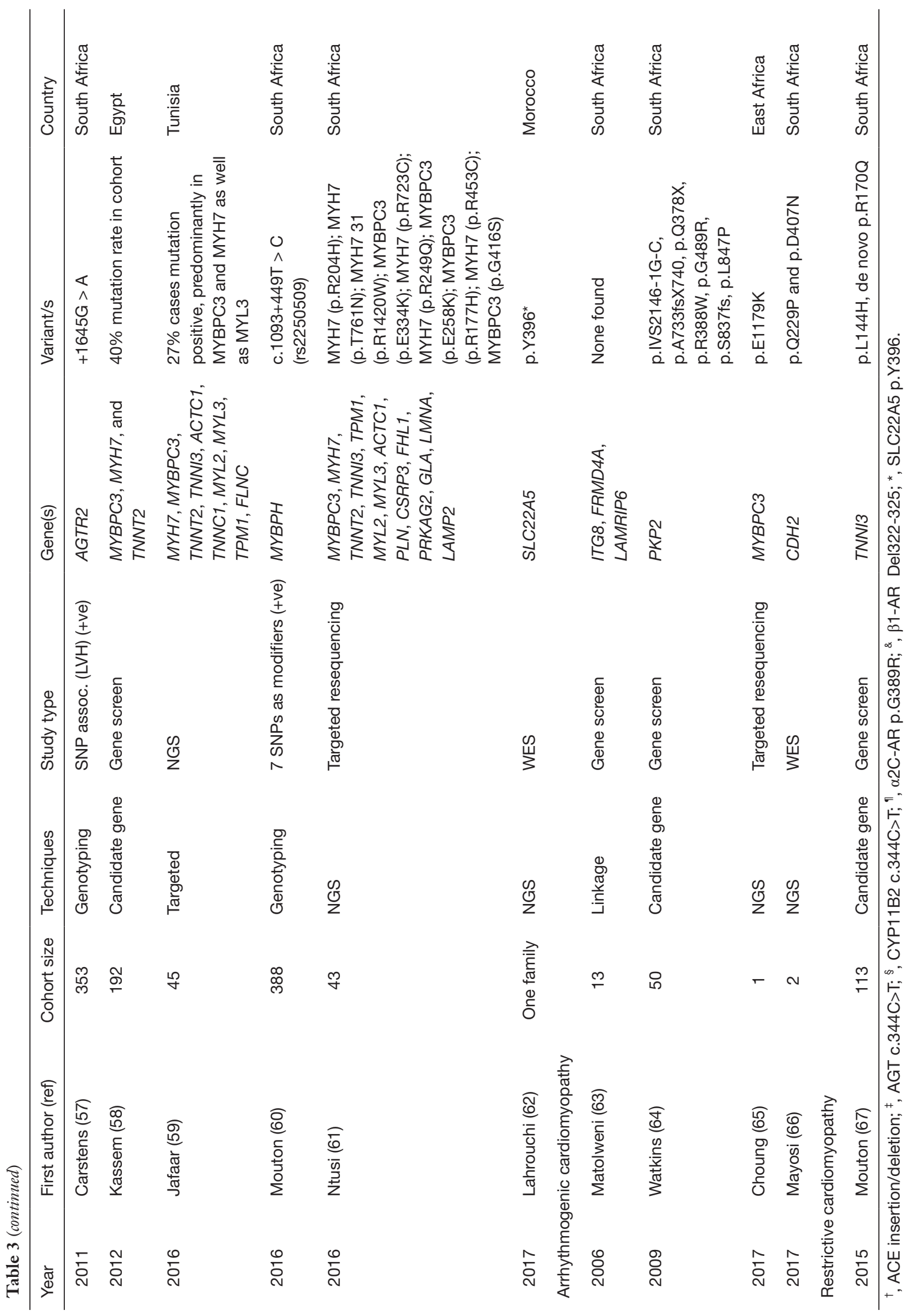




\section{Genetics of HCM}

HCM is a monogenic disorder caused by mutations in genes that encode sarcomere proteins. Incomplete penetrance is seen within families and is hypothesised to be due to additional environmental, genetic or epigenetic factors. Genetic testing sensitivity for familial HCM is $50-60 \%(78,79)$. Of individuals with known mutations, $70 \%$ harbour mutations within either the $\beta$-myosin heavy chain $(M Y H 7)$ or myosin-binding protein $\mathrm{C}$ (MYBPC3) genes. $M Y H 7$ mutations are associated with high disease penetrance and moderate to severe LV hypertrophy (LVH), while MYBPC3 mutations manifest in mid- to lateadulthood with mild to moderate $\mathrm{LVH}$ and a relatively good prognosis. Troponin T2 gene (TNNT2) mutations account for around $5 \%$ of disease, with a high incidence of SCD even with minimal LVH (14). Despite $>1,400$ known mutations, the downstream cardiomyocyte metabolic effects are largely similar, characterised by an increased energetic cost of contraction and reduced cycling of ATP, resulting in heightened cardiac contraction and faulty relaxation, and reduced overall sarcomeric power $(61,80,81)$.

We reviewed the available literature on studies reporting on the genetics of HCM in Africa and identified 18 studies: 15 conducted in South Africa and one in Egypt, one in Tunisia and another in Morocco (Table 3); only 3 of these studies employed NGS technology $(59,61,62)$. These studies gave new insights into the functional effects of genetic mutations on disease mechanism and pathogenesis of HCM in the South African families. In 1993, a group in South Africa performed the first candidate gene study on the African continent in an HCM cohort of five unrelated index cases of mixed ancestry. This relatively small pioneering HCM study identified the first African index case with a mutation in $M Y H 7$ (p.Arg403Trp) and led the way in genetic discoveries in HCM for the next two decades. They reported nine mutations (six of which were novel) in a South African HCM population consisting of mixed ancestry and white individuals of northern-European descent: MYH7: p.Arg249Gln, p.Arg403Trp, p.Ala797Thr (novel), p.Gly499Lys (novel), p.Arg719Gln; TNNT2: p.Arg92Trp (novel); MYBPC3:Arg654His (novel), $\Delta \mathrm{c} 756$ (novel), Val896Met (novel). The group also found that none of the other HCM disease-associated mutations that had been reported worldwide occurred in their South African HCM cohort. Further candidate gene screens detected the presence of the $M Y H 7$ p.Arg403Trp, $M Y H 7$ p.Ala797Thr and cTNNT2 p.Arg92Trp mutations in 1, 8, and 4 probands, respectively. This was very different from the profiles seen in most North American and European referral centres, where numerous "private" $M Y H 7$ mutations are reported to account for $40-70 \%$ of HCM (61).

Cognisant of the history of South Africa and colonisation by Europeans in the 17th century, they hypothesised that the recurring mutations were due to founder mutations. Founder-gene effects are not uncommon in South Africa, especially among the Afrikaner subgroup of the white population (82-87). These founder effects are probably due to bottlenecks in gene transmission, caused by rapid expansion of the white population in the Western Cape after the initial colonisation by the Dutch in $1652(82,83)$. The mixing of genes from the Europeans and the indigenous people of South Africa like the Khoikhoi, the San and later also with the Xhosa people, and indentured slaves from Malaysia led to the origin of the mixed ancestry population "Cape Coloureds" of South Africa, known to be the most genetically admixed population in the world. Linkage studies performed in families carrying these recurring mutations allowed for tracing of their origin to three common ancestors in the Western and Eastern Cape provinces, where the $M Y H 7$ p.Ala797Thr mutation accounts for $25 \%$ of the HCM cases, cTNNT2 p.Arg92Trp is the causative mutation in $15 \%$, and $M Y H 7$ p.Arg 403 Trp in $5 \%$ of affected individuals. Collectively, the $5 \mathrm{MYH7}$ mutations (Arg249Gln, p.Arg403Trp, p.Glu499Lys, p.Arg719Gln, p.Ala797Thr) were responsible for disease in $37.5 \%$ of HCM cohorts in the South African subpopulations studied. Reports showed that the $M Y H 7$ mutations have distinct cardiac functional effects in HCM patients without hypertrophy (88). Specifically, the $M Y H 7$ p.Arg403Trp mutation is a strong predictor of the development of LV dilation and systolic and diastolic dysfunction in later life $(50,89)$. Milder phenotypes of the MYH7 mutations may account for the high presence of these founder mutations within the HCM cohorts in South Africa. Long-term follow-up of founder families with HCM showed that all carriers of the TNNT2 p.Arg92Trp mutation (who typically have no cardiac hypertrophy during their youth) developed hypertrophy after the age of 35 years. The distinct functional effect of the TNNT2 p.R92W mutation resulted in a relative increase in systolic functional parameter and an abnormal blood pressure response to exercise occurred more commonly in HCM patients with the TNNT2 p.R92W mutation than in those with $M H Y 7$ mutations (45). These observations may be relevant to the understanding of the high mortality 
associated with TNNT2 p.R92W mutation despite minimal evidence of cardiac hypertrophy (50). Despite the large percentage of founder mutations, there were also many novel mutations, which led to the researchers proposing that the profile of HCM-causing mutations would be unique in different geographic areas and that it is the result of numerous nascent mutations.

Advancements in genetic technology led to the first NGS study on an HCM cohort conducted on the African continent. In the study by Jaafar et al., targeted resequencing was used to screen nine known HCM genes in a cohort of 45 Tunisian patients (59). They reported a $27 \%$ mutation detection rate, predominantly in $M Y B P C 3$ and $M Y H 7$ although $F L N C$ and $M Y L 3$ mutations were also found. This study pointed to the heterogeneous genetic background of Tunisians, but founder mutations were not present at a high rate among Tunisians. The other NGS study by our group showed the same basic genetic yield of $29 \%$ (61) with both studies showing a much lower rate than the global frequencies for HCM. These few studies have made some important contributions to understanding the genetic basis of HCM in Africa, but what is clear is that many more African genetics studies need to be conducted to provide important insights into about the genetics of HCM.

\section{Arrhythmogenic cardiomyopathy}

$\mathrm{ACM}$ is an inherited disease of cell-to-cell junctions resulting in electrical instability and risk of SCD. Currently, $\mathrm{ACM}$ is the only cardiomyopathy whose diagnostic criteria incorporate the presence of a known genetic mutation (90). ACM has both a higher incidence and severity of disease in male patients $(14,91-93)$. As there are no prevalence data available on ACM in Africa, we aimed to obtain an estimate by searching the literature for studies reporting on the incidence of ACM and found 3 hospital-based studies (Tables 2,S2) (94-96). The largest study occurred in Tanzania where 815 adult CVD patients were screened but only 2 patients were reported to have ACM (71).

\section{Genetics of ACM}

To date, 15 genes have been reported to cause ACM (97-101). Amongst these, 5 causal desmosomal genes have been identified, including plakophilin 2 (PKP2) (102), desmoplakin (DSP) (103), desmoglein-2 (DSG2) (104) and desmoscollin-2 (DSC2) (105), and junctional-plakophilin (JUP) (106). Together, these genes account for only $50 \%$ of ACM, so it is likely that other causal genes are yet to be identified $(81,107)$. The genetics of ACM have been suggested to be more complex than the simple monogenic heritability as in some cases patients with ACM have more than 1 mutation in the same gene (compound heterozygosity) or in another modifier gene (digenic heterozygosity) (108). Analyses of first- and second-degree relatives of patients with ACM suggest that up to $50 \%$ of ACM cases are familial. ACM is most commonly inherited as an autosomal dominant trait with incomplete penetrance $(98,99,109)$, although 2 autosomal recessive forms have been described (110). As penetrance is incomplete, genetically affected relatives often demonstrate variable and mild (or no) phenotype and the prevalence of familial disease is often underestimated in clinical practice $(91,97,111)$. Genetic testing for ACM using a larger cardiomyopathy panel may identify non-desmosomal genes with pathogenic variants. Similarly, desmosomal gene pathogenic variations have also been identified in patients diagnosed with DCM (16). Exercise has a well-established role in the pathogenesis of desmosomal cardiomyopathies, and recognition of a desmosomal gene mutation can help to determine optimal exercise recommendations $(112,113)$.

Genetically determined disruption of the integrity of the intercalated disk is a key factor promoting the development of ACM and SCD. Loss of desmosomal integrity can substantially affect gap junctions, sodium channel function and electrical propagation, thereby promoting ventricular arrhythmias in the absence of overt structural damage $(114,115)$ and thus providing an overlapping phenotype (cardiomyopathy plus arrhythmias) because of disruption of 2 "final common pathways" (desmosome and ion channel) $(116,117)$.

We reviewed the available literature on the genetics of ACM in Africa and identified 4 studies (3 conducted in South Africa by our group) (Table 3) (63-66) that used a molecular genetics approach to determine the cause of disease in ACM cohorts: the first ACM study in Africa was done in 2006 on a large South African family where linkage was used to narrow the region but no disease-causing mutation was found (63). Twenty years later, and with the advent of new technologies such as NGS, we used WES on 2 cousins (in the three-generation family studied in 2006) with ACM. We identified a novel mutation in $\mathrm{CDH} 2$ (p.Gln229Pro) as the cause of disease in this family, as well as a second $C D H 2$ (p.Asp407Asn) variant after screening a cohort of 73 genotype-negative ACM probands. In 2009, our group reported a candidate gene screening of the PKP2 
gene and found 7 mutations in $25 \%$ of the ACM cases, 5 being novel. We reported on the novel PKP2 p.Arg388Trp mutation which occurred in 4 white South Africans who shared a common haplotype, prompting us to suggest a possible founder mutation. Finally, in 2017, Choung et al. reported the ACM-related loss of a young mother and athlete from East Africa in the third trimester of an uneventful pregnancy. A cardiac panel with known disease genes was used for screening; however, a heterozygous variant of unknown significance (VUS) was found in $M Y B P C 3$, so no genetic cause was found. Two of these 4 studies on ACM on the African continent have reported novel, private mutations and highlights the possibility that SSA could provide some very important insights into ACM and identify other possible disease mechanisms which might shed some light on the different pathways that lead to ACM.

\section{Restrictive cardiomyopathy}

RCM represents a very small fraction $(<5 \%)$ of all cardiomyopathies in HICs, both in paediatric (118) and in adult populations, although prevalence may be more common in certain regions including Nigeria, Malawi, Ivory Coast, Mozambique and Uganda (119). Endomyocardial fibrosis (EMF) is a common cause of RCM causing impaired filling of one or both ventricles. Some reports suggest clinical overlap between RCM and HCM $(15,120,121)$. The aetiology of EMF remains poorly understood, though evidence points towards eosinophilic inflammation and fibrosis possibly related to parasitic infections $(25,122)$. As there is no prevalence data available on RCM in Africa, we searched the literature to obtain an estimate for the incidence of RCM and found 8 articles (Tables 2,S2). The largest studies occurred in Ethiopia $(n=6,275)$ and Malawi $(\mathrm{n}=3,908)$ but only 7 and 3 patients were reported to have RCM, respectively $(14,28)$.

\section{Genetics of RCM}

Familial RCM usually has autosomal dominant inheritance, but autosomal recessive, $\mathrm{X}$-linked and mitochondrialtransmitted disease occurs. Most of the identified genes encode sarcomere or Z-disk proteins, such as TNNI3, TNNT2, MYH7, ACTC1, TPM1, MYL3, and MYL $(35,123)$ (Table 3). Z-disk protein-encoding genes, including $M Y P N, T T N$, and $B A G 3$, have also been identified $(97,99,101,124,125)$. Missense variants in DES have been identified in several families with desmin-related myopathy, which can present with RCM, with or without skeletal myopathy and/or atrioventricular block. A recent study identified a pathogenic variant in $60 \%$ of subjects, primarily occurring in genes known to cause HCM (126). Family members were frequently identified with HCM or HCM with restrictive physiology. Transthyretin (TTR) is a gene is associated with amyloid-related RCM (125) and pathogenic variants in the TTR gene needs to be differentiated from other forms of RCM due to the age demographic in which this occurs, the slowly progressive nature of this disease, and therefore different management strategies $(127,128)$. The TTR allele p.Val142Ile has been found in $10 \%$ of African Americans older than 65 years of age with severe congestive HF (112).

We reviewed all the available literature on studies reporting on the genetics of RCM in Africa and identified only 1 study (Table 3). Mouton et al. reported the first, and only, study on the genetics of RCM in Africa in 2015. They hypothesised that mutations in TNNI3 could underlie HCM with restrictive features in $115 \mathrm{HCM}$ probands. They found a novel disease-causing TNNTI3 p.Leu144His mutation and a de novo p.Arg170Gln mutation associated with RCM and focal ventricular hypertrophy, often below the typical diagnostic threshold for HCM. This result is not surprising though, as it is well established that genes of the sarcomere can cause HCM, DCM and RCM (67). However, this 1 available RCM study in Africa highlights the urgent need for additional genetic studies on this continent that will shed more light on RCM disease pathogenesis in this setting.

\section{Left ventricular noncompaction}

LVNC is a heterogeneous myocardial disorder characterised by prominent trabeculae that are most evident in the LV apex, intratrabecular recesses, and LV myocardium with 2 distinct layers: compacted and noncompacted myocardium $(97,99,129,130)$. The LVNC phenotype may be observed in conjunction with all other cardiomyopathy phenotypes (112), so considerations related to genetic testing should always be directed by findings of a cardiomyopathy (or other cardiovascular) phenotype $(131,132)$. Our search yielded 5 articles from Africa on LVNC (Tables 2,S2) with low incidence rates. The largest study occurred in Sudan $(n=4,500)$ but only 22 patients were reported to have LVNC (11). 


\section{Genetics of LVNC}

LVNC has been associated with mutations in $>40$ genes and a number of chromosomal defects (133). The former includes genes involved in muscular dystrophies (e.g., $D M D$, $L M N A, D M P K)$, congenital and hereditary myopathies (e.g., MYH7, RYR1, TPM1, TAZ) and metabolic/ mitochondrial disorders (e.g., LAMP2, GBE1, SDHD, $H A D H B)$ (134-137). Notably, mutations in sarcomere genes (e.g., $M Y H 7, M Y B P C 3)$ are identifiable in a significant proportion (around 30\%) of isolated LVNC. However, causation has yet to be established, with attendant variable recommendations for genetic testing. LVNC is familial in $30-50 \%$ of cases, with autosomal dominant (e.g., $M Y H 7$ ), autosomal recessive, X-linked (e.g., the multisystem Barth syndrome resulting from a mutation in TAZ) and maternal (mitochondrial) inheritance patterns described. In view of this, first-degree relatives of index patients should undergo echocardiographic screening $(14,133)$. We did not find any reports on the genetics of LVNC in African countries.

\section{Conclusions}

Africa is dealing with the colliding epidemics of communicable disease and rapidly expanding epidemics of NCDs, which include HF. Our review has highlighted the large gaps in knowledge on inherited cardiomyopathies, particularly in SSA. Health systems throughout Africa are overburdened and understaffed and in desperate need of improvement. If the current trajectory is not altered, Africa will continue to face an increase in the burden of CVD and patient mortality will continue to escalate.

We have summarised the data on the molecular genetic underpinnings of cardiomyopathy in Africa. Little is known about the aetiology and outcome of cardiomyopathy, especially related to the inherited cardiomyopathies: DCM, HCM, ACM, RCM and LVNC. While many genes have been identified as the cause of inherited cardiomyopathies outside of Africa, there have been relatively few publications on genetics of cardiomyopathies in SSA $(4,27,138,139)$. Over the years though, genetics has moved from single gene screens to next generation sequencing (NGS) where entire genomes can now be sequenced by small laboratories and researchers are able to study biological systems at a level never before possible. NGS creates a single platform for the molecular genetic screening of the cardiomyopathies of interest in Africa and will go a long way to filling the large gaps in knowledge on the genetics of the inherited cardiomyopathies in Africa.

\section{Acknowledgments}

Funding: Drs Shaboodien and Ntusi gratefully acknowledge support from the National Research Foundation and the Medical Research Council of South Africa. In addition, Dr Ntusi also acknowledges support from the Harry Crossley Foundation and Lily \& Ernst Hausmann Trust.

\section{Footnote}

Provenance and Peer Review: This article was commissioned by the Guest Editor (Ntobeko A. B. Ntusi) for the series "Cardiovascular Diseases in Low- and Middle-Income Countries" published in Cardiovascular Diagnosis and Therapy. The article was sent for external peer review organized by the Guest Editor and the editorial office.

Conflicts of Interest: All authors have completed the ICMJE uniform disclosure form (available at http://dx.doi.org/10.21037/ cdt.2019.10.03). The series "Cardiovascular Diseases in Low-and Middle-Income Countries" was commissioned by the editorial office without any funding or sponsorship. NABN served as the unpaid Guest Editor of the series, and acknowledges funding from the South African Medical Research Council, National Research Foundation, the Harry Crossley Foundation and the Lily and Ernst Hausmann Trust. The authors have no other conflicts of interest to declare.

Ethical Statement: The authors are accountable for all aspects of the work in ensuring that questions related to the accuracy or integrity of any part of the work are appropriately investigated and resolved.

Open Access Statement: This is an Open Access article distributed in accordance with the Creative Commons Attribution-NonCommercial-NoDerivs 4.0 International License (CC BY-NC-ND 4.0), which permits the noncommercial replication and distribution of the article with the strict proviso that no changes or edits are made and the original work is properly cited (including links to both the formal publication through the relevant DOI and the license). See: https://creativecommons.org/licenses/by-nc-nd/4.0/. 


\section{References}

1. Bloomfield GS, Barasa FA, Doll JA, et al. Heart failure in sub-Saharan Africa. Curr Cardiol Rev 2013;9:157-73.

2. Maher D, Smeeth L, Sekajugo J. Health transition in Africa: practical policy proposals for primary care. Bull World Health Organ 2010;88:943-8.

3. Sliwa K. The heart of Africa: succeeding against the odds. Lancet 2016;388:e28-36.

4. Sliwa K, Mayosi BM. Recent advances in the epidemiology, pathogenesis and prognosis of acute heart failure and cardiomyopathy in Africa. Heart 2013;99:1317-22.

5. Sliwa K, Ntusi N. Battling Cardiovascular Diseases in a Perfect Storm. Circulation 2019;139:1658-60.

6. Mensah GA, Roth GA, Sampson UK, et al. Mortality from cardiovascular diseases in sub-Saharan Africa, 1990-2013: a systematic analysis of data from the Global Burden of Disease Study 2013. Cardiovasc J Afr 2015;26:S6-10.

7. Keates AK, Mocumbi AO, Ntsekhe M, et al. Cardiovascular disease in Africa: epidemiological profile and challenges. Nat Rev Cardiol 2017;14:273-93.

8. Ntusi NB, Mayosi BM. Epidemiology of heart failure in sub-Saharan Africa. Expert Rev Cardiovasc Ther 2009;7:169-80.

9. Schocken DD, Benjamin EJ, Fonarow GC, et al. Prevention of heart failure: a scientific statement from the American Heart Association Councils on Epidemiology and Prevention, Clinical Cardiology, Cardiovascular Nursing, and High Blood Pressure Research; Quality of Care and Outcomes Research Interdisciplinary Working Group; and Functional Genomics and Translational Biology Interdisciplinary Working Group. Circulation 2008; 117:2544-65.

10. Amoah AG, Kallen C. Aetiology of heart failure as seen from a National Cardiac Referral Centre in Africa. Cardiology 2000;93:11-8.

11. Damasceno A, Cotter G, Dzudie A, et al. Heart failure in sub-saharan Africa: time for action. J Am Coll Cardiol 2007;50:1688-93.

12. Agbor VN, Essouma M, Ntusi NAB, et al. Heart failure in sub-Saharan Africa: A contemporaneous systematic review and meta-analysis. Int J Cardiol 2018;257:207-15.

13. Falase AO, Ogah OS. Cardiomyopathies and myocardial disorders in Africa: present status and the way forward. Cardiovasc J Afr 2012;23:552-62.

14. Chan K, Harper AR, Ashrafian H, et al. Cardiomyopathies. Medicine 2018;46:606-17.

15. Towbin JA. Inherited cardiomyopathies. Circ J
2014;78:2347-56.

16. Elliott $\mathrm{P}, \mathrm{O}^{\prime}$ Mahony C, Syrris $\mathrm{P}$, et al. Prevalence of desmosomal protein gene mutations in patients with dilated cardiomyopathy. Circ Cardiovasc Genet 2010;3:314-22.

17. Ware JS, Li J, Mazaika E, et al. Shared Genetic Predisposition in Peripartum and Dilated Cardiomyopathies. N Engl J Med 2016;374:233-41.

18. Watkins H, Ashrafian H, Redwood C. Inherited cardiomyopathies. N Engl J Med 2011;364:1643-56.

19. GBD 2015 Disease and Injury Incidence and Prevalence Collaborators. Global, regional, and national incidence, prevalence, and years lived with disability for 310 diseases and injuries, 1990-2015: a systematic analysis for the Global Burden of Disease Study 2015. Lancet 2016;388:1545-602.

20. McKenna WJ, Maron BJ, Thiene G. Classification, Epidemiology, and Global Burden of Cardiomyopathies. Circ Res 2017;121:722-30.

21. Ansa V, Otu A, Oku A, et al. Patient outcomes following after-hours and weekend admissions for cardiovascular disease in a tertiary hospital in Calabar, Nigeria. Cardiovasc J Afr 2016;27:328-32.

22. Damasceno A, Mayosi BM, Sani M, et al. The causes, treatment, and outcome of acute heart failure in 1006 Africans from 9 countries. Arch Intern Med 2012;172:1386-94.

23. Dokainish H, Teo K, Zhu J, et al. Heart Failure in Africa, Asia, the Middle East and South America: The INTERCHF study. Int J Cardiol 2016;204:133-41.

24. Sliwa K, Damasceno A, Mayosi BM. Epidemiology and etiology of cardiomyopathy in Africa. Circulation 2005;112:3577-83.

25. Kwan GF, Jean-Baptiste W, Cleophat P, et al. Descriptive epidemiology and short-term outcomes of heart failure hospitalisation in rural Haiti. Heart 2016;102:140-6.

26. Ntusi NB, Badri M, Gumedze F, et al. Clinical characteristics and outcomes of familial and idiopathic dilated cardiomyopathy in Cape Town: a comparative study of 120 cases followed up over 14 years. S Afr Med J 2011;101:399-404.

27. Alfieri O, Mayosi BM, Park SJ, et al. Exploring unknowns in cardiology. Nat Rev Cardiol 2014;11:664-70.

28. Truszkowska GT, Bilinska ZT, Kosinska J, et al. A study in Polish patients with cardiomyopathy emphasizes pathogenicity of phospholamban (PLN) mutations at amino acid position 9 and low penetrance of heterozygous null PLN mutations. BMC Med Genet 2015;16:21. 
29. Hershberger RE, Morales A, Siegfried JD. Clinical and genetic issues in dilated cardiomyopathy: a review for genetics professionals. Genet Med 2010;12:655-67.

30. Bowles NE, Bowles KR, Towbin JA. The "final common pathway" hypothesis and inherited cardiovascular disease. The role of cytoskeletal proteins in dilated cardiomyopathy. Herz 2000;25:168-75.

31. Mizusawa Y. Recent advances in genetic testing and counseling for inherited arrhythmias. J Arrhythm 2016;32:389-97.

32. Adadi N, Radi FZ, Lahrouchi N, et al. Inherited dilated cardiomyopathy in a large Moroccan family caused by LMNA mutation. Anatol J Cardiol 2018;20:65-8.

33. Dellefave L, McNally EM. The genetics of dilated cardiomyopathy. Curr Opin Cardiol 2010;25:198-204.

34. Forissier JE, Bonne G, Bouchier C, et al. Apical left ventricular aneurysm without atrio-ventricular block due to a lamin $\mathrm{A} / \mathrm{C}$ gene mutation. Arch Mal Coeur Vaiss 2005;98:67-70.

35. Debold EP, Schmitt JP, Patlak JB, et al. Hypertrophic and dilated cardiomyopathy mutations differentially affect the molecular force generation of mouse alpha-cardiac myosin in the laser trap assay. Am J Physiol Heart Circ Physiol 2007;293:H284-91.

36. Ehler E, Perriard JC. Cardiomyocyte cytoskeleton and myofibrillogenesis in healthy and diseased heart. Heart Fail Rev 2000;5:259-69.

37. Candy GP, Skudicky D, Mueller UK, et al. Association of left ventricular systolic performance and cavity size with angiotensin-converting enzyme genotype in idiopathic dilated cardiomyopathy. Am J Cardiol 1999;83:740-4.

38. Tiago AD, Badenhorst D, Skudicky D, et al. An aldosterone synthase gene variant is associated with improvement in left ventricular ejection fraction in dilated cardiomyopathy. Cardiovasc Res 2002;54:584-9.

39. Badenhorst D, Norton GR, Sliwa K, et al. Impact of beta2-adrenoreceptor gene variants on cardiac cavity size and systolic function in idiopathic dilated cardiomyopathy. Pharmacogenomics J 2007;7:339-45.

40. Du Preez J, Matolweni LO, Greenberg J, et al. The alpha 2C Del322-325 adrenergic receptor polymorphism is not associated with heart failure due to idiopathic dilated cardiomyopathy in black Africans. Cardiovasc J Afr 2008;19:15-6.

41. Woodiwiss AJ, Badenhorst D, Sliwa K, et al. Beta1- and alpha2c-adrenoreceptor variants as predictors of clinical aspects of dilated cardiomyopathy in people of African ancestry. Cardiovasc J Afr 2008;19:188-93.
42. Mahjoub S, Mehri S, Bousaada R, et al. Association of ACE I/D polymorphism in Tunisian patients with dilated cardiomyopathy. J Renin Angiotensin Aldosterone Syst 2010;11:187-91.

43. Sayed S, Idriss NK, Blann A, et al. The Number of GT(n) Repeats in the Hemeoxygenase-1 Gene Promoter is Increased in Pediatric Heart Failure but is Unrelated to Renal, Antioxidant and Anti-inflammatory Markers. Pediatr Cardiol 2015;36:1204-11.

44. Fish M, Shaboodien G, Kraus S, et al. Mutation analysis of the phospholamban gene in 315 South Africans with dilated, hypertrophic, peripartum and arrhythmogenic right ventricular cardiomyopathies. Sci Rep 2016;6:22235.

45. Heradien M, Revera M, van der Merwe L, et al. Abnormal blood pressure response to exercise occurs more frequently in hypertrophic cardiomyopathy patients with the R92W troponin T mutation than in those with myosin mutations. Heart Rhythm 2009;6:S18-24.

46. Moolman JC, Brink PA, Corfield VA. Identification of a new missense mutation at Arg403, a CpG mutation hotspot, in exon 13 of the beta-myosin heavy chain gene in hypertrophic cardiomyopathy. Hum Mol Genet 1993;2:1731-2.

47. Moolman JC, Brink PA, Corfield VA. Identification of a novel Ala797Thr mutation in exon 21 of the beta-myosin heavy chain gene in hypertrophic cardiomyopathy. Hum Mutat 1995;6:197-8.

48. Posen BM, Moolman JC, Corfield VA, et al. Clinical and prognostic evaluation of familial hypertrophic cardiomyopathy in two South African families with different cardiac beta myosin heavy chain gene mutations. Br Heart J 1995;74:40-6.

49. Tesson F, Dufour C, Moolman JC, et al. The influence of the angiotensin I converting enzyme genotype in familial hypertrophic cardiomyopathy varies with the disease gene mutation. J Mol Cell Cardiol 1997;29:831-8.

50. Moolman JC, Corfield VA, Posen B, et al. Sudden death due to troponin T mutations. J Am Coll Cardiol 1997;29:549-55.

51. Moolman-Smook JC, Mayosi B, Brink P, et al. Identification of a new missense mutation in MyBP-C associated with hypertrophic cardiomyopathy. J Med Genet 1998;35:253-4.

52. Moolman-Smook JC, De Lange WJ, Bruwer EC, et al. The origins of hypertrophic cardiomyopathy-causing mutations in two South African subpopulations: a unique profile of both independent and founder events. Am J Hum Genet 1999;65:1308-20. 
53. Andersen PS, Havndrup O, Bundgaard H, et al. Myosin light chain mutations in familial hypertrophic cardiomyopathy: phenotypic presentation and frequency in Danish and South African populations. J Med Genet 2001;38:E43.

54. Blair E, Redwood C, de Jesus Oliveira M, et al. Mutations of the light meromyosin domain of the beta-myosin heavy chain rod in hypertrophic cardiomyopathy. Circ Res 2002;90:263-9.

55. Moolman-Smook J, De Lange W, Corfield V, et al. Expression of HCM causing mutations: lessons learnt from genotype-phenotype studies of the South African founder MYH7 A797T mutation. J Med Genet 2000;37:951-6.

56. van der Merwe L, Cloete R, Revera M, et al. Genetic variation in angiotensin-converting enzyme 2 gene is associated with extent of left ventricular hypertrophy in hypertrophic cardiomyopathy. Hum Genet 2008;124:57-61.

57. Carstens N, van der Merwe L, Revera M, et al. Genetic variation in angiotensin II type 2 receptor gene influences extent of left ventricular hypertrophy in hypertrophic cardiomyopathy independent of blood pressure. J Renin Angiotensin Aldosterone Syst 2011;12:274-80.

58. Kassem H, Azer RS, Saber-Ayad M, et al. Early results of sarcomeric gene screening from the Egyptian National BA-HCM Program. J Cardiovasc Transl Res 2013;6:65-80.

59. Jaafar N, Gomez J, Kammoun I, et al. Spectrum of Mutations in Hypertrophic Cardiomyopathy Genes Among Tunisian Patients. Genet Test Mol Biomarkers 2016;20:674-9.

60. Mouton JM, van der Merwe L, Goosen A, et al. MYBPH acts as modifier of cardiac hypertrophy in hypertrophic cardiomyopathy (HCM) patients. Hum Genet 2016;135:477-83.

61. Ntusi NA, Shaboodien G, Badri M, et al. Clinical features, spectrum of causal genetic mutations and outcome of hypertrophic cardiomyopathy in South Africans. Cardiovasc J Afr 2016;27:152-8.

62. Lahrouchi N, Behr ER, Bezzina CR. Next-Generation Sequencing in Post-mortem Genetic Testing of Young Sudden Cardiac Death Cases. Front Cardiovasc Med 2016;3:13.

63. Matolweni LO, Bardien S, Rebello G, et al. Arrhythmogenic right ventricular cardiomyopathy type 6 (ARVC6): support for the locus assignment, narrowing of the critical region and mutation screening of three candidate genes. BMC Med Genet 2006;7:29.

64. Watkins DA, Hendricks N, Shaboodien G, et al. Clinical features, survival experience, and profile of plakophylin-2 gene mutations in participants of the arrhythmogenic right ventricular cardiomyopathy registry of South Africa. Heart Rhythm 2009;6:S10-7.

65. Choung HYG, Vyas M, Jacoby D, et al. Arrhythmogenic Right Ventricular Cardiomyopathy (ARVC) in a young female athlete at 36 weeks gestation: a case report. Pathol Res Pract 2017;213:1302-5.

66. Mayosi BM, Fish M, Shaboodien G, et al. Identification of Cadherin 2 (CDH2) Mutations in Arrhythmogenic Right Ventricular Cardiomyopathy. Circ Cardiovasc Genet 2017;10.

67. Mouton JM, Pellizzon AS, Goosen A, et al. Diagnostic disparity and identification of two TNNI3 gene mutations, one novel and one arising de novo, in South African patients with restrictive cardiomyopathy and focal ventricular hypertrophy. Cardiovasc J Afr 2015;26:63-9.

68. Haghighi K, Kolokathis F, Gramolini AO, et al. A mutation in the human phospholamban gene, deleting arginine 14, results in lethal, hereditary cardiomyopathy. Proc Natl Acad Sci U S A 2006;103:1388-93.

69. Haghighi K, Kolokathis F, Pater L, et al. Human phospholamban null results in lethal dilated cardiomyopathy revealing a critical difference between mouse and human. J Clin Invest 2003;111:869-76.

70. Schmitt JP, Kamisago M, Asahi M, et al. Dilated cardiomyopathy and heart failure caused by a mutation in phospholamban. Science 2003;299:1410-3.

71. Maron BJ, Casey SA, Poliac LC, et al. Clinical course of hypertrophic cardiomyopathy in a regional United States cohort. Jama 1999;281:650-5.

72. Lewis BS, Armstrong TG, Mitha AS, et al. Hypertrophic obstructive cardiomyopathy in the South African Bantu. S Afr Med J 1973;47:599-604.

73. Maro EE, Janabi M, Kaushik R. Clinical and echocardiographic study of hypertrophic cardiomyopathy in Tanzania. Trop Doct 2006;36:225-7.

74. Lewis BS, Agathangelou NE, Flax H, et al. Hypertrophic cardiomyopathy in South African Blacks. S Afr Med J 1983;63:266-70.

75. Abegaz B. The impact of echocardiography in the diagnosis of hypertrophic cardiomyopathy. East Afr Med J 1990;67:556-67.

76. Soliman EZ, Juma H. Cardiac disease patterns in northern Malawi: epidemiologic transition perspective. J Epidemiol 2008;18:204-8.

77. Yadeta D, Guteta S, Alemayehu B, et al. Spectrum of cardiovascular diseases in six main referral hospitals of 
Ethiopia. Heart Asia 2017;9:e010829.

78. Gersh BJ, Maron BJ, Bonow RO, et al. 2011 ACCF/AHA guideline for the diagnosis and treatment of hypertrophic cardiomyopathy: executive summary: a report of the American College of Cardiology Foundation/American Heart Association Task Force on Practice Guidelines. J Am Coll Cardiol 2011;58:2703-38.

79. Hershberger RE, Lindenfeld J, Mestroni L, et al. Genetic evaluation of cardiomyopathy--a Heart Failure Society of America practice guideline. J Card Fail 2009;15:83-97.

80. Burke MA, Cook SA, Seidman JG, et al. Clinical and Mechanistic Insights Into the Genetics of Cardiomyopathy. J Am Coll Cardiol 2016;68:2871-86.

81. Wilcox JE, Hershberger RE. Genetic cardiomyopathies. Curr Opin Cardiol 2018;33:354-62.

82. Botha MC, Beighton P. Inherited disorders in the Afrikaner population of southern Africa. Part I. Historical and demographic background, cardiovascular, neurological, metabolic and intestinal conditions. S Afr Med J 1983;64:609-12.

83. Botha MC, Beighton P. Inherited disorders in the Afrikaner population of southern Africa. Part II. Skeletal, dermal and haematological conditions; the Afrikaners of Gamkaskloof; demographic considerations. S Afr Med J 1983;64:664-7.

84. Brink PA, Brink LT, Torrington M, et al. Linkage study of the low-density lipoprotein-receptor gene and cholesterol levels in an Afrikaner family. Quantitative genetics and identification of a minor founder effect. S Afr Med J 1990;77:292-6.

85. Kotze MJ, Langenhoven E, Warnich L, et al. The molecular basis and diagnosis of familial hypercholesterolaemia in South African Afrikaners. Ann Hum Genet 1991;55:115-21.

86. Warnich L, Kotze MJ, Groenewald IM, et al. Identification of three mutations and associated haplotypes in the protoporphyrinogen oxidase gene in South African families with variegate porphyria. Hum Mol Genet 1996;5:981-4.

87. de Jager T, Corbett CH, Badenhorst JC, et al. Evidence of a long QT founder gene with varying phenotypic expression in South African families. J Med Genet 1996;33:567-73.

88. Revera M, van der Merwe L, Heradien M, et al. Troponin $\mathrm{T}$ and beta-myosin mutations have distinct cardiac functional effects in hypertrophic cardiomyopathy patients without hypertrophy. Cardiovasc Res 2008;77:687-94.

89. Revera M, Van der Merwe L, Heradien M, et al. Longterm follow-up of R403WMYH7 and R92WTNNT2
HCM families: mutations determine left ventricular dimensions but not wall thickness during disease progression. Cardiovasc J Afr 2007;18:146-53.

90. Marcus FI, McKenna WJ, Sherrill D, et al. Diagnosis of arrhythmogenic right ventricular cardiomyopathy/ dysplasia: proposed modification of the Task Force Criteria. Eur Heart J 2010;31:806-14.

91. Azaouagh A, Churzidse S, Konorza T, et al. Arrhythmogenic right ventricular cardiomyopathy/ dysplasia: a review and update. Clin Res Cardiol 2011;100:383-94.

92. Peters S, Trummel M, Meyners W. Prevalence of right ventricular dysplasia-cardiomyopathy in a non-referral hospital. Int J Cardiol 2004;97:499-501.

93. Rampazzo A, Nava A, Danieli GA, et al. The gene for arrhythmogenic right ventricular cardiomyopathy maps to chromosome 14q23-q24. Hum Mol Genet 1994;3:959-62.

94. Behairy NH, Mansour, S. M. . Pattern of delayed myocardial enhancement: A key to differentiate ischemic and non-ischemic cardiomyopathies The Egyptian Journal of Radiology and Nuclear Medicine 2014;45:53-60.

95. James OO, Efosa JD, Romokeme AM, et al. Dominance of hypertensive heart disease in a tertiary hospital in southern Nigeria: an echocardiographic study. Ethn Dis 2012;22:136-9.

96. Raphael DM, Roos L, Myovela V, et al. Heart diseases and echocardiography in rural Tanzania: Occurrence, characteristics, and etiologies of underappreciated cardiac pathologies. PLoS One 2018;13:e0208931.

97. Ackerman MJ, Priori SG, Willems S, et al. HRS/EHRA expert consensus statement on the state of genetic testing for the channelopathies and cardiomyopathies this document was developed as a partnership between the Heart Rhythm Society (HRS) and the European Heart Rhythm Association (EHRA). Heart Rhythm 2011;8:1308-39.

98. Ellinor PT, MacRae CA, Thierfelder L. Arrhythmogenic right ventricular cardiomyopathy. Heart Fail Clin 2010;6:161-77.

99. Maron BJ, Towbin JA, Thiene G, et al. Contemporary definitions and classification of the cardiomyopathies: an American Heart Association Scientific Statement from the Council on Clinical Cardiology, Heart Failure and Transplantation Committee; Quality of Care and Outcomes Research and Functional Genomics and Translational Biology Interdisciplinary Working Groups; and Council on Epidemiology and Prevention. Circulation 2006;113:1807-16. 
100. Te Rijdt WP, Jongbloed JD, de Boer RA, et al. Clinical utility gene card for: arrhythmogenic right ventricular cardiomyopathy (ARVC). Eur J Hum Genet 2014;22.

101. Teekakirikul P, Kelly MA, Rehm HL, et al. Inherited cardiomyopathies: molecular genetics and clinical genetic testing in the postgenomic era. J Mol Diagn 2013;15:158-70.

102. Gerull B, Heuser A, Wichter T, et al. Mutations in the desmosomal protein plakophilin-2 are common in arrhythmogenic right ventricular cardiomyopathy. Nat Genet 2004;36:1162-4.

103. Rampazzo A, Nava A, Malacrida S, et al. Mutation in human desmoplakin domain binding to plakoglobin causes a dominant form of arrhythmogenic right ventricular cardiomyopathy. Am J Hum Genet 2002;71:1200-6.

104.Pilichou K, Nava A, Basso C, et al. Mutations in desmoglein-2 gene are associated with arrhythmogenic right ventricular cardiomyopathy. Circulation 2006;113:1171-9.

105. Syrris P, Ward D, Evans A, et al. Arrhythmogenic right ventricular dysplasia/cardiomyopathy associated with mutations in the desmosomal gene desmocollin-2. Am J Hum Genet 2006;79:978-84.

106. McKoy G, Protonotarios N, Crosby A, et al. Identification of a deletion in plakoglobin in arrhythmogenic right ventricular cardiomyopathy with palmoplantar keratoderma and woolly hair (Naxos disease). Lancet 2000;355:2119-24.

107. Corrado D, Link MS, Calkins H. Arrhythmogenic Right Ventricular Cardiomyopathy. N Engl J Med 2017;376:1489-90.

108.Xu T, Yang Z, Vatta M, et al. Compound and digenic heterozygosity contributes to arrhythmogenic right ventricular cardiomyopathy. J Am Coll Cardiol 2010;55:587-97.

109.Hamid MS, Norman M, Quraishi A, et al. Prospective evaluation of relatives for familial arrhythmogenic right ventricular cardiomyopathy/dysplasia reveals a need to broaden diagnostic criteria. J Am Coll Cardiol 2002;40:1445-50.

110. Protonotarios N, Tsatsopoulou A. Naxos disease and Carvajal syndrome: cardiocutaneous disorders that highlight the pathogenesis and broaden the spectrum of arrhythmogenic right ventricular cardiomyopathy. Cardiovasc Pathol 2004;13:185-94.

111. Saffitz JE. Arrhythmogenic cardiomyopathy: advances in diagnosis and disease pathogenesis. Circulation 2011;124:e390-2.
112.Hershberger RE, Givertz MM, Ho CY, et al. Genetic Evaluation of Cardiomyopathy-A Heart Failure Society of America Practice Guideline. J Card Fail 2018;24:281-302.

113. James CA, Bhonsale A, Tichnell C, et al. Exercise increases age-related penetrance and arrhythmic risk in arrhythmogenic right ventricular dysplasia/ cardiomyopathy-associated desmosomal mutation carriers. J Am Coll Cardiol 2013;62:1290-7.

114.Delmar M, McKenna WJ. The cardiac desmosome and arrhythmogenic cardiomyopathies: from gene to disease. Circ Res 2010;107:700-14.

115. Noorman M, Hakim S, Kessler E, et al. Remodeling of the cardiac sodium channel, connexin43, and plakoglobin at the intercalated disk in patients with arrhythmogenic cardiomyopathy. Heart Rhythm 2013;10:412-9.

116. Towbin JA, Lorts A. Arrhythmias and dilated cardiomyopathy common pathogenetic pathways? J Am Coll Cardiol 2011;57:2169-71.

117. Vatta M, Marcus F, Towbin JA. Arrhythmogenic right ventricular cardiomyopathy: a 'final common pathway' that defines clinical phenotype. Eur Heart J 2007;28:529-30.

118.Lee TM, Hsu DT, Kantor P, et al. Pediatric Cardiomyopathies. Circ Res 2017;121:855-73.

119. Masarone D, Kaski JP, Pacileo G, et al. Epidemiology and Clinical Aspects of Genetic Cardiomyopathies. Heart Fail Clin 2018;14:119-28.

120. Rivenes SM, Kearney DL, Smith EO, et al. Sudden death and cardiovascular collapse in children with restrictive cardiomyopathy. Circulation 2000;102:876-82.

121. Walsh MA, Grenier MA, Jefferies JL, et al. Conduction abnormalities in pediatric patients with restrictive cardiomyopathy. Circ Heart Fail 2012;5:267-73.

122. Bukhman G, Ziegler J, Parry E. Endomyocardial fibrosis: still a mystery after 60 years. PLoS Negl Trop Dis 2008;2:e97.

123. Caleshu C, Sakhuja R, Nussbaum RL, et al. Furthering the link between the sarcomere and primary cardiomyopathies: restrictive cardiomyopathy associated with multiple mutations in genes previously associated with hypertrophic or dilated cardiomyopathy. Am J Med Genet A 2011;155a:2229-35.

124.Purevjav E, Varela J, Morgado M, et al. Nebulette mutations are associated with dilated cardiomyopathy and endocardial fibroelastosis. J Am Coll Cardiol 2010;56:1493-502.

125.Sen-Chowdhry S, Syrris P, McKenna WJ. Genetics of restrictive cardiomyopathy. Heart Fail Clin 2010;6:179-86.

126. Gallego-Delgado M, Delgado JF, Brossa-Loidi V, et al. 
Idiopathic Restrictive Cardiomyopathy Is Primarily a Genetic Disease. J Am Coll Cardiol 2016;67:3021-3.

127. Rapezzi C, Lorenzini M, Longhi S, et al. Cardiac amyloidosis: the great pretender. Heart Fail Rev 2015;20:117-24.

128. Ton VK, Mukherjee M, Judge DP. Transthyretin cardiac amyloidosis: pathogenesis, treatments, and emerging role in heart failure with preserved ejection fraction. Clin Med Insights Cardiol 2015;8:39-44.

129. Towbin JA. Left ventricular noncompaction: a new form of heart failure. Heart Fail Clin 2010;6:453-69, viii.

130. Towbin JA, Bowles NE. The failing heart. Nature 2002;415:227-33.

131. Arbustini E, Weidemann F, Hall JL. Left ventricular noncompaction: a distinct cardiomyopathy or a trait shared by different cardiac diseases? J Am Coll Cardiol 2014;64:1840-50.

132. Probst S, Oechslin E, Schuler P, et al. Sarcomere gene mutations in isolated left ventricular noncompaction cardiomyopathy do not predict clinical phenotype. Circ Cardiovasc Genet 2011;4:367-74.

133. Finsterer J, Stollberger C, Towbin JA. Left ventricular

Cite this article as: Shaboodien G, Spracklen TF, Kamuli S, Ndibangwi P, Van Niekerk C, Ntusi NA. Genetics of inherited cardiomyopathies in Africa. Cardiovasc Diagn Ther 2020;10(2):262-278. doi: 10.21037/cdt.2019.10.03 noncompaction cardiomyopathy: cardiac, neuromuscular, and genetic factors. Nat Rev Cardiol 2017;14:224-37.

134. Ouyang P, Saarel E, Bai Y, et al. A de novo mutation in NKX2.5 associated with atrial septal defects, ventricular noncompaction, syncope and sudden death. Clin Chim Acta 2011;412:170-5.

135. Postma AV, van Engelen K, van de Meerakker J, et al. Mutations in the sarcomere gene MYH7 in Ebstein anomaly. Circ Cardiovasc Genet 2011;4:43-50.

136. Udeoji DU, Philip KJ, Morrissey RP, et al. Left ventricular noncompaction cardiomyopathy: updated review. Ther Adv Cardiovasc Dis 2013;7:260-73.

137.Vermeer AM, van Engelen K, Postma AV, et al. Ebstein anomaly associated with left ventricular noncompaction: an autosomal dominant condition that can be caused by mutations in MYH7. Am J Med Genet C Semin Med Genet 2013;163c:178-84.

138. Dato I. How to recognize endomyocardial fibrosis? J Cardiovasc Med (Hagerstown) 2015;16:547-51.

139. Peters F, Khandheria BK. Isolated left ventricular noncompaction: what do we really know? Curr Cardiol Rep 2012;14:381-8. 
Supplementary

Table S1 Abbreviations

\begin{tabular}{ll} 
Abbreviation & Defintition \\
\hline$A_{2 C}-A R$ & Adrenoceptor alpha 2C
\end{tabular}

ACE Angiotensin I converting enzym

ACE2 Angiotensin I converting enzyme

ACM Arrhythmogenic cardiomyopathy

AGT

AGTR2 Angiotensin II receptor type 2

AIDS Acquired immune deficiency syndrome

ALA Alanine

ALU Arthrobacter luteus

ARG Arginine

Asparagine

Aspartic acid

Adenosine triphosphate

BCL2 associated athanogene 3

Adrenoceptor beta 1

Adrenoceptor beta 2

Beta myosin heavy chain

Congenital heart disease

Cadherin-2

Cardiomyopathy

Cardiovascular magnetic resonance

Cysteine and glycine rich protein 3

Cardiovascular disease

Cytochrome P450 family 11 subfamily B member 2

Dilated cardiomyopathy

Dystrophia myotonica protein kinas

Desmoscollin-2

Desmoglein-2

Desmoplakin

Electrocardiogram

Echocardiogram

Endomyocardial fibrosis

Four and a half LIM domains

Filamin C

FERM domain containing $4 \mathrm{~A}$

1,4-alpha-glucan branching enzyme

Galactosidase alpha

Glutamine

Glycine

Hydroxyacyl-CoA dehydrogenase trifunctional multienzyme complex subunit beta

Hypertrophic cardiomyopathy

Heart failure

Heart failure with mildly reduced ejection fraction

Heart failure with preserved ejection fraction

Heart failure with reduced ejection fraction

Histidine

Human immunodeficiency virus

Haem oxygenase 1

Implantable cardioverter defibirilators

Junctional-plakophilin

Lysosomal associated membrane protein 2

Laminin receptor 1 pseudogene 6

Leucine

Low- and middle-income countries

Lamin A/C

Left ventricular

LV end-diastolic diameter

Left ventricular ejection fraction

Left ventricular hypertrophy

Left ventricular noncompaction

Methionin

myosin-binding protein $C$

b-myosin heavy chain

Myosin light chain 2

Myosin light chain 3

Myopalladin

Noncommunicable disease

Next generation sequencing

New York Heart Association

Plakophilin2

Phospholamban

Peripartum cardiomyopathy

Protein kinase AMP-activated non-catalytic subunit gamma

Proline

Restrictive cardiomyopathy

Rheumatic heart disease

Right ventricular

Ryanodine receptor 1

Sudden cardiac death

Succinate dehydrogenase complex subunit

Single nucleotide polymorphism

Sub-Saharan Africa

Tafazzin

Threonine

Troponin 13, cardiac type

Troponin T2

Tropomyosin 1

Tryptophan

Transthyretin

United States

Ventricular tachycardia

Variant of unknown significance

WES Whole exome sequencing 


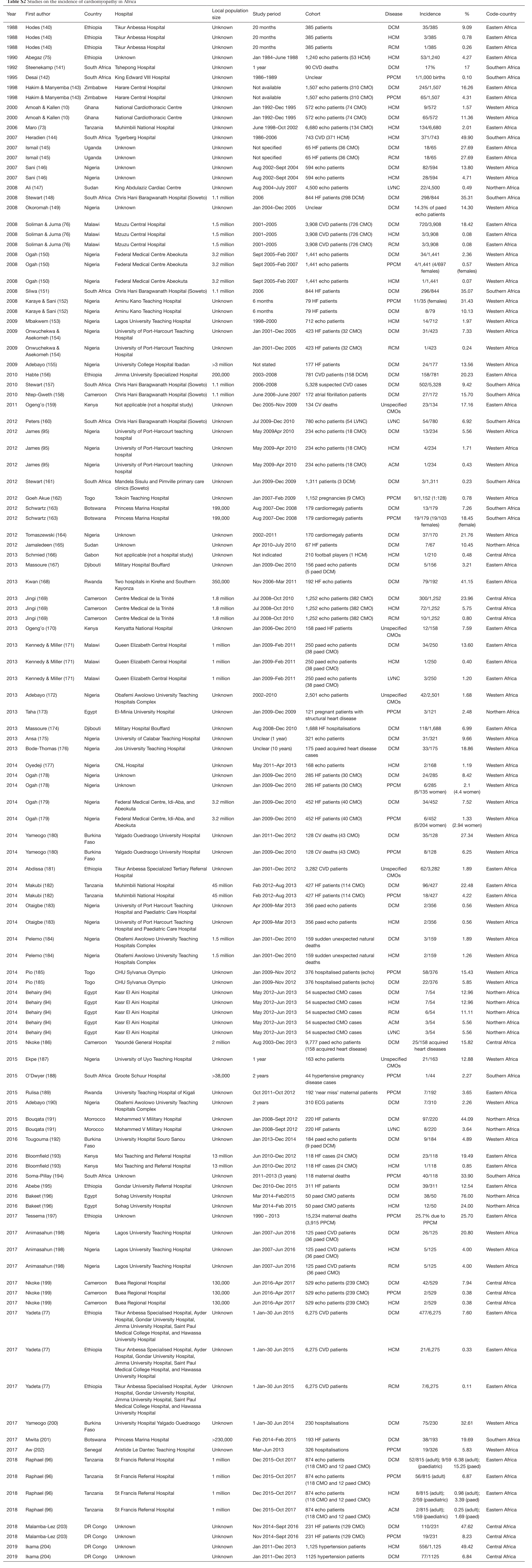




\section{References}

140. Hodes RM. Pattern of heart disease in Ethiopia as seen in a cardiology referral clinic. Cardiology 1988;75:458-64.

141. Steenekamp JH, Simson IW, Theron W. Cardiovascular causes of death at Tshepong Hospital in 1 year, 1989-1990. A necropsy study. S Afr Med J 1992;81:142-6.

142. Desai D, Moodley J, Naidoo D. Peripartum cardiomyopathy: experiences at King Edward VIII Hospital, Durban, South Africa and a review of the literature. Trop Doct 1995;25:118-23.

143. Hakim JG, Manyemba J. Cardiac disease distribution among patients referred for echocardiography in Harare, Zimbabwe. Cent Afr J Med 1998;44:140-4.

144.Heradien M, Goosen A, Moolman-Smook JC, et al. Race and gender representation of hypertrophic cardiomyopathy or long QT syndrome cases in a South African research setting. Cardiovasc J Afr 2007;18:312-5.

145. Ismail Y, Andia I, Byaruhanga S, et al. Echocardiographic features of cardiac failure in Uganda. Trop Doct 2007;37:267-8.

146. Sani MU, Karaye KM, Ibrahim DA. Cardiac morbidity in subjects referred for echocardiographic assessment at a tertiary medical institution in the Nigerian savanna zone. Afr J Med Med Sci 2007;36:141-7.

147.Ali SK. Unique features of non-compaction of the ventricular myocardium in Arab and African patients. Cardiovasc J Afr 2008;19:241-5.

148. Stewart S, Wilkinson D, Hansen C, et al. Predominance of heart failure in the Heart of Soweto Study cohort: emerging challenges for urban African communities. Circulation 2008;118:2360-7.

149. Okoromah CA, Ekure EN, Ojo OO, et al. Structural heart disease in children in Lagos: profile, problems and prospects. Niger Postgrad Med J 2008;15:82-8.

150. Ogah OS, Adegbite GD, Akinyemi RO, et al. Spectrum of heart diseases in a new cardiac service in Nigeria: an echocardiographic study of 1441 subjects in Abeokuta. BMC Res Notes 2008;1:98.

151.Sliwa K, Wilkinson D, Hansen C, et al. Spectrum of heart disease and risk factors in a black urban population in South Africa (the Heart of Soweto Study): a cohort study. Lancet 2008;371:915-22.

152. Karaye KM, Sani MU. Factors associated with poor prognosis among patients admitted with heart failure in a Nigerian tertiary medical centre: a cross-sectional study. BMC Cardiovasc Disord 2008;8:16.

153.Amam Mbakwem DOaJA. Hypertrophic cardiomyopathy in South Western Nigeria : hypertrophic cardiomyopathy. SA Heart 2009;6:104-19.

154. Onwuchekwa AC, Asekomeh GE. Pattern of heart failure in a Nigerian teaching hospital. Vasc Health Risk Manag 2009;5:745-50.

155. Adebayo AK, Adebiyi AA, Oladapo OO, et al. Characterisation of heart failure with normal ejection fraction in a tertiary hospital in Nigeria. BMC Cardiovasc Disord 2009;9:52.

156. Habte B, Alemseged F, Tesfaye D. The pattern of cardiac diseases at the cardiac clinic of jimma university specialised hospital, South west ethiopia. Ethiop J Health Sci 2010;20:99-105.

157. Stewart S, Carrington M, Pretorius S, et al. Standing at the crossroads between new and historically prevalent heart disease: effects of migration and socio-economic factors in the Heart of Soweto cohort study. Eur Heart J 2011;32:492-9.

158. Ntep-Gweth M, Zimmermann M, Meiltz A, et al. Atrial fibrillation in Africa: clinical characteristics, prognosis, and adherence to guidelines in Cameroon. Europace 2010;12:482-7.

159. Ogeng'o JA, Gatonga P, Olabu BO. Cardiovascular causes of death in an east African country: an autopsy study. Cardiol J 2011;18:67-72.

160.Peters F, Khandheria BK, dos Santos C, et al. Isolated left ventricular noncompaction in sub-Saharan Africa: a clinical and echocardiographic perspective. Circ Cardiovasc Imaging 2012;5:187-93.

161. Stewart S, Carrington MJ, Pretorius S, et al. Elevated risk factors but low burden of heart disease in urban African primary care patients: a fundamental role for primary prevention. Int J Cardiol 2012;158:205-10.

162. Goeh Akue KE, Assou K, Kossidze K, et al. Peripartum myocardiopathy in Lome (Togo). Int J Cardiol 2012;157:e12-3.

163. Schwartz T, Magdi G, Steen TW, et al. HIV as a risk factor for cardiac disease in Botswana: a cross-sectional study. Int Health 2012;4:30-7.

164. Tomaszewski R. Cardiomegaly in tropical Africa. Int Marit Health 2012;63:56-8.

165. Jamaledeen M, Ali SK. Correlation of clinical and echocardiographic scores with blood "brain natriuretic peptide" in paediatric patients with heart failure. East Afr Med J 2012;89:359-62.

166. Schmied C, Di Paolo FM, Zerguini AY, et al. Screening athletes for cardiovascular disease in Africa: a challenging experience. Br J Sports Med 2013;47:579-84. 
167. Massoure PL, Roche NC, Lamblin G, et al. Cardiovascular disease in children in Djibouti: a single-centre study. Pan Afr Med J 2013;14:141.

168.Kwan GF, Bukhman AK, Miller AC, et al. A simplified echocardiographic strategy for heart failure diagnosis and management within an integrated noncommunicable disease clinic at district hospital level for sub-Saharan Africa. JACC Heart Fail 2013;1:230-6.

169. Jingi AM, Noubiap JJ, Kamdem P, et al. The spectrum of cardiac disease in the West Region of Cameroon: a hospital-based cross-sectional study. Int Arch Med 2013;6:44.

170.Ogeng'o JA, Gatonga PM, Olabu BO, et al. Pattern of congestive heart failure in a Kenyan paediatric population. Cardiovasc J Afr 2013;24:117-20.

171. Kennedy N, Miller P. The spectrum of paediatric cardiac disease presenting to an outpatient clinic in Malawi. BMC Res Notes 2013;6:53.

172. Adebayo RA, Akinwusi PO, Balogun MO, et al. Twodimensional and Doppler echocardiographic evaluation of patients presenting at Obafemi Awolowo University Teaching Hospitals Complex, Ile-Ife, Nigeria: a prospective study of 2501 subjects. Int J Gen Med 2013;6:541-4.

173. Taha NM, Mahmoud KS, Eisa MK, et al. Structural heart disease in pregnancy in El-Minia localities. The Egyptian Heart Journal 2013;65:99-109.

174. Massoure PL, Roche NC, Lamblin G, et al. Heart failure patterns in Djibouti: epidemiologic transition. Med Sante Trop 2013;23:211-6.

175.Ansa VO, Odigwe CO, Agbulu RO, et al. The clinical utility of echocardiography as a cardiological diagnostic tool in poor resource settings. Niger J Clin Pract 2013;16:82-5.

176. Bode-Thomas F, Ige OO, Yilgwan C. Childhood acquired heart diseases in Jos, north central Nigeria. Niger Med J 2013;54:51-8.

177. Oyedeji AT, Akintunde AA, Owojori OO, et al. Spectrum of Echocardiographic Abnormalities among 168 Consecutive Referrals to an Urban Private Hospital in South-Western Nigeria. Clin Med Insights Cardiol 2014;8:35-8.

178. Ogah OS, Stewart S, Falase AO, et al. Short-term outcomes after hospital discharge in patients admitted with heart failure in Abeokuta, Nigeria: data from the Abeokuta Heart Failure Registry. Cardiovasc J Afr 2014;25:217-23.

179. Ogah OS, Stewart S, Falase AO, et al. Contemporary profile of acute heart failure in Southern Nigeria: data from the Abeokuta Heart Failure Clinical Registry. JACC Heart Fail 2014;2:250-9.

180. Yameogo AR, Mandi G, Millogo G, et al. Assessing causes of death in the Cardiology Department of Yalgado Ouedraogo University Hospital. Pan Afr Med J 2014;19:155.

181. Abdissa SG, Oli K, Feleke Y, et al. Spectrum of cardiovascular diseases among Ethiopian patients at Tikur Anbessa Specialized University Teaching Hospital, Addis Ababa. Ethiop Med J 2014;52:9-17.

182. Makubi A, Hage C, Lwakatare J, et al. Contemporary aetiology, clinical characteristics and prognosis of adults with heart failure observed in a tertiary hospital in Tanzania: the prospective Tanzania Heart Failure (TaHeF) study. Heart 2014;100:1235-41.

183. Otaigbe BE, Tabansi PN. Congenital heart disease in the Niger Delta region of Nigeria: a four-year prospective echocardiographic analysis. Cardiovasc J Afr 2014;25:265-8.

184. Pelemo OE, Sabageh D, Komolafe AO, et al. An autopsy review of sudden unexpected natural deaths in a suburban Nigerian population. Population Health Metrics 2014;12.

185.Pio M, Goeh-Akue E, Afassinou Y, et al. Young heart failure: epidemiological, clinical and etiological aspects in the teaching hospital Sylvanus Olympio of Lome. Ann Cardiol Angeiol (Paris) 2014;63:240-4.

186. Nkoke C, Menanga A, Boombhi J, et al. A new look at acquired heart diseases in a contemporary sub-Saharan African pediatric population: the case of Yaounde, Cameroon. Cardiovasc Diagn Ther 2015;5:428-34.

187.Ekpe EE, Ikpe MC, Umoh I. Echocardiographic pattern of acquired heart diseases in Nigeria. Niger Med J 2015;56:253-7.

188. O'Dwyer SL, Gupta M, Anthony J. Pulmonary edema in pregnancy and the puerperium: a cohort study of 53 cases. J Perinat Med 2015;43:675-81.

189. Rulisa S, Umuziranenge I, Small M, et al. Maternal near miss and mortality in a tertiary care hospital in Rwanda. BMC Pregnancy Childbirth 2015;15:203.

190. Adebayo RA, Ikwu AN, Balogun MO, et al. Heart rate variability and arrhythmic patterns of 24-hour Holter electrocardiography among Nigerians with cardiovascular diseases. Vasc Health Risk Manag 2015;11:353-9.

191. Bouqata N, Kheyi J, Miftah F, et al. Epidemiological and evolutionary characteristics of heart failure in patients with left bundle branch block - A Moroccan center-based study. J Saudi Heart Assoc 2015;27:1-9.

192. Tougouma SJ, Kissou SA, Yameogo AA, et al. 
Cardiopathies in children hospitalized at the University hospital Souro Sanou, Bobo-Dioulasso: echocardiographic and therapeutic aspects. Pan Afr Med J 2016;25:62.

193. Bloomfield GS, DeLong AK, Akwanalo CO, et al. Markers of Atherosclerosis, Clinical Characteristics, and Treatment Patterns in Heart Failure: A Case-Control Study of Middle-Aged Adult Heart Failure Patients in Rural Kenya. Glob Heart 2016;11:97-107.

194. Soma-Pillay P, Seabe J, Sliwa K. The importance of cardiovascular pathology contributing to maternal death: Confidential Enquiry into Maternal Deaths in South Africa, 2011-2013. Cardiovasc J Afr 2016;27:60-5.

195.Abebe TB, Gebreyohannes EA, Tefera YG, et al. Patients with HFpEF and HFrEF have different clinical characteristics but similar prognosis: a retrospective cohort study. BMC Cardiovasc Disord 2016;16:232.

196. Bakeet MA, Mohamed MM, Allam AA, et al. Childhood Cardiomyopathies: A Study in Tertiary Care Hospital in Upper Egypt. Electron Physician 2016;8:3164-9.

197. Tessema GA, Laurence CO, Melaku YA, et al. Trends and causes of maternal mortality in Ethiopia during 19902013: findings from the Global Burden of Diseases study 2013. BMC Public Health 2017;17:160.

198. Animasahun BA, Madise-Wobo AD, Kusimo OY. Nigerian
Children with Acquired Heart Disease: The Experience in Lagos. J Tehran Heart Cent 2017;12:160-6.

199. Nkoke C, Makoge C, Dzudie A, et al. A predominance of hypertensive heart disease among patients with cardiac disease in Buea, a semi-urban setting, South West Region of Cameroon. BMC Res Notes 2017;10:684.

200. Yameogo AR, Millogo GRC, Palm AF, et al. Evaluation of patients' satisfaction in the department of cardiology at the University Hospital Yalgado Ouedraogo. Pan Afr Med J 2017;28:267.

201.Mwita JC, Dewhurst MJ, Magafu MG, et al. Presentation and mortality of patients hospitalised with acute heart failure in Botswana. Cardiovasc J Afr 2017;28:112-7.

202.Aw F, Ndiaye MB, Sarr S, et al. Prevalence and characteristics of dysfunction of right ventricle in peripartum cardiomyopathy. Research Reports in Clinical Cardiology 2017;8:61-6.

203.Malamba-Lez D, Ngoy-Nkulu D, Steels P, et al. Heart Failure Etiologies and Challenges to Care in the Developing World: An Observational Study in the Democratic Republic of Congo. J Card Fail 2018;24:854-9.

204.Ikama MS, Makani J, Nsitou BM, et al. [Echocardiographic profile of Congolese hypertensive patients]. Ann Cardiol Angeiol (Paris) 2019;68:32-8. 